\title{
ANALISIS RUANG PUBLIK INSTAGRAM BEMP ILMU KOMUNIKASI UNIVERSITAS NEGERI JAKARTA SEBAGAI TRANSFORMASI INFORMASI
}

\author{
Febrizka Nabilla $^{1 *}$, Kiki Dwi Arviani², Rizka Herlina ${ }^{3}$, Dini Safitri ${ }^{4}$ \\ ${ }^{1,2,3,4}$ Universitas Negeri Jakarta, Jakarta Timur, Indonesia \\ *febrizkanabilla@gmail.com
}

\begin{abstract}
One of the important factors in delivering information transformation is the intensity of the followers. With the intensity of the followers that causes the information reported by an information submitted by the Instagram account of BEMP Communication Science, State University of Jakarta. The purpose of this study is to see the information transformation process that occurs on the BEMP Instagram account of the Jakarta State University for communication. This research uses qualitative research methods with interview and observation data techniques. The results of this study indicate that Instagram of BEMP Communication Science, State University of Jakarta is a place for public spaces in statements of attitudes and arguments. In addition, the information transformation that occurs includes criticism and suggestions from his followers, this can happen because the information conveyed can influence the various opinions and responses of his followers, then what the followers think. The occurrence of this transformation made his followers more generous in visiting the Instagram account of BEMP Communication Science, State University of Jakarta, because they wanted information for themselves that could be obtained by visiting the Instagram account of BEMP Communication Science, State University of Jakarta.
\end{abstract}

Keywords: Public Space, Information Transformation, Instagram

\begin{abstract}
Abstrak
Salah satu faktor penting dalam penyampaian transformasi informasi adalah intensitas para pengikut. Dengan adanya intensitas dari para pengikut menyebabkan terjadinya transformasi informasi yang ditandai dengan mudah dimengertinya suatu informasi yang disampaikan oleh akun Instagram BEMP Ilmu Komunikasi Universitas Negeri Jakarta. Penelitian ini memiliki tujuan yakni mencari tahu proses transformasi informasi yang terjadi di akun instagram BEMP Ilmu Komunikasi Universitas Negeri Jakarta. Penelitian ini menggunakan metode penelitian kualitatif dengan teknik pengumpulan data melalui wawancara dan observasi. Hasil penelitian ini menunjukan bahwa Instagram BEMP Ilmu Komunikasi Universitas Negeri Jakarta menjadi wadah sebagai ruang publik dalam menyatakan sikap dan argumen. Selain itu, transformasi informasi yang terjadi memuat kritik dan saran dari para pengikutnya, hal ini dapat terjadi lantaran dengan informasi yang disampaikan dapat memengaruhi berbagai pendapat serta respon dari para pengikutnya, kemudian apa yang menjadi pemikiran dari para pengikut. Terjadinya transformasi ini membuat para pengikutnya menjadi lebih intens dalam mengunjungi akun instagram BEMP Ilmu Komunikasi Universitas Negeri Jakarta, karena mereka menginginkan adanya informasi untuk diri mereka sendiri yang bisa diperoleh dengan cara mengunjungi akun instagram BEMP Ilmu Komunikasi Universitas Negeri Jakarta.
\end{abstract}

Kata Kunci: Ruang Publik, Transformasi Informasi, Instagram

\section{PENDAHULUAN}

Pada saat ini penyebaran informasi oleh media konvensional tidak hanya melalui satu saluran utama saja melainkan juga memiliki akun media sosial sebagai tempat mereka untuk menyebarkan informasi dan berinteraksi dengan khalayak. Media sosial merupakan alat komunikasi yang terkenal 
saat ini. Kegunaan media sosial untuk berinteraksi juga semakin beragam terutama karena kemudahan aksesnya dalam penyebaran informasi (Wahyudin \& Adiputra, 2019). Media sosial instagram sudah mulai dikembangkan sejak tahun 2010. Instagram sendiri merupakan bentuk aplikasi berbagi foto serta video yang memberikan penggunanya kesempatan untuk memotret foto, merekam video, menambahkan aneka macam filter yang tersedia serta membagikannya (Prihatiningsih, 2017). Fitur-fitur yang ada pada instagram juga dilengkapi dengan kolom komentar yang berfungsi untuk menuangkan komentar dari para penggunanya. Instagram sebagai tempat menyebarkan foto dan video sangat menguntungkan bagi pihak-pihak yang memanfaatkannya. Instagram merupakan media konvensional, di mana Penggunaan instagram sebagai ruang publik memanfaatkan fitur berbagi foto dan video yang bisa dilihat oleh banyak orang dan memungkinkan setiap orang untuk terlibat di dalamnya. Hal ini disebabkan karena instagram dapat memainkan peran sebagai sarana komunikasi saat ini (Insani et al., 2019).

Media sosial sebagai turunan dari internet sekarang ini menjadi ruang terbuka secara digital yang bisa dimanfaatkan oleh semua orang tanpa terkecuali. Media sosial memungkinkan setiap orang untuk berpartisipasi di dalamnya (Salman, 2017). Melalui media sosial, semua orang mempunyai kesempatan yang sama untuk berkomentar, membagikan informasi, dan bahkan beradu pendapat. Berbagai media sosial hadir sebagai pengisi waktu luang maupun sebagai wadah untuk berkomunikasi. Seperti halnya aplikasi instagram yang hadir sebagai wadah untuk berkomunikasi. Instagram merupakan aplikasi yang muncul pertama kali pada 06 Oktober 2010. Aplikasi ini sangat populer menjadi aplikasi untuk berbagi foto dan video di kalangan anak muda. Penggunaan aplikasi instagram ini banyak digunakan sebagai wadah untuk berbagi informasi melalui gambar ataupun video. (Shaleh \& Furrie, 2020)

Seperti halnya yang dilakukan oleh BEMP Ilmu Komunikasi Universitas Negeri Jakarta yang memanfaatkan media sosial instagram sebagai wadah untuk menyebarkan informasi seputar kegiatan BEMP Ilmu Komunikasi Universitas Negeri Jakarta. Penggunaan instagram sebagai wadah untuk menyebarkan informasi ini memungkinkan bagi setiap pengikutnya untuk terlibat komunikasi di dalamnya. Selain itu, penggunaan instagram juga berfungsi sebagai sarana transformasi informasi dinilai efektif sebab pesan yang disampaikan akan langsung terkirim ke semua pengikutnya (Sari \& Basit, 2020).

Ruang publik yang dimaksud dalam penelitian ini bukan merupakan ruang publik yang menjadi tempat untuk hubungan pasar misalnya penjualan dan pembelian tetapi merupakan tempat untuk hubunganhubungan yang berbeda-beda dan menjadi tempat terjadi perdebatan dan permusyawaratan (Dwihantoro et al., 2020) .Bentuk konsep ruang publik salah satunya adalah media sosial, sangat dimaklumi apabila media sosial digunakan oleh para pengguna media dalam perkara ini para anggota BEMP Ilmu Komunikasi Universitas Negeri Jakarta untuk menyebarluaskan segala bentuk informasi kegiatan BEMP Ilmu Komunikasi Universitas Negeri Jakarta dalam menjalankan maupun bertanggung jawab atas peran dan tugasnya.

Sebutan ruang publik pertama kali dikenalkan oleh Jurgen Habermas. Habermas memaknai ruang publik sebagai wadah tertuangnya pertukaran dan pertumpahan bermacam-macam argumen atau gagasan kultural, politik, ekonomi, maupun sosial (Andri et al., 2020). Menurut sejarah, dahulu ruang publik dimaknai sebagai tempat pertemuan, diskusi. Di berbagai ruang publik itulah masing-masing anggotanya bisa saling menyampaikan ide 
serta gagasan dengan tidak adanya tekanan dari para petinggi. Seiring berjalannya waktu, dalam lingkungan modern, saat ini media digunakan sebagai ruang public (Tricana, 2013). Habermas juga mengatakan bahwa ruang publik dimaknai sebagai bagian paling penting untuk negara demokrasi. Demokrasi bisa berlaku secara optial apabila pada dalam suatu negara memiliki ruang publik yang setara yang mana semua individu mempunyai kesempatan yang setara dalam keikut sertaan, menyuarakan gagasannya, dan memberikan informasi (Salman, 2017). Teori yang membahas mengenai ruang sudah sering dikemukakan oleh banyak pemikir kritis di Era Posmodern, misalnya Michel Foucault, John Gaventa, Henri Lefebvre, dan Jurgen Habermas. Foucault menyebutkan bahwasanya ruang hanyalah praktik kekuasaan. Dalam konteks penyebutan ruang, dikatakan bahwa Habermas dan Lefebvre menyebutnya sebagai produk sosial yang senantiasa mengalami perkembangan sejalan dengan masyarakat yang juga mengalami perkembangan, ruang mempunyai sifat yang dinamis. Media baru atau yang kerap disebut sebagai digital media, dicirikan dengan informasi yang gampang dipalsukan, dibuat dalam jaringan, padat, mudah diminimalkan, dan tampaknya tidak dimiliki pemiliknya. Berdasarkan wataknya yang virtual, interaktif, terintegrasi, serta global, berarti internet ada berperan sebagai ruang publik yang lebih luas. Media baru menciptakan ruang publik dalam skala internasional (Istiarni \& Kurniasari, 2020).

Transformasi informasi sendiri didefinisikan sebagai bagian dari langkahlangkah dalam pengelolaan sistem informasi yang fungsinya adalah untuk mengolah data menjadi informasi sehingga bisa didapatkan produk informasi yang kita butuhkan. Berdasarkan konsepnya, transformasi informasi merupakan satu proses perubahan bentuk, watak, serta tanda-tanda dari sebuah data sehingga menjadi sebuah informasi untuk disebarluaskan atau didokumentasikan. Transformasi informasi memiliki fokus terhadap hal-hal antara lain, (1) mengumpulkan data, (2) mengelolah sekaligus menganalisis data, (3) penyajian sekaligus penyebaran informasi, serta (4) penataan dokumentasi sekaligus perpustakaan. Selain melibatkan setiap pengikut, penggunaan instagram juga melahirkan kebebasan bersuara bagi para pengikutnya. Berdasarakan Poespowardojo, inti ide yang disampaikan oleh Habermas mengenai demokrasi dimana pada masyarakat kapitalis membuat ruang public dengan sifat bebas dan terbuka untuk masyarakat agar semua pihak dapat dilibatkan dalam mengambil keputusan publik.

Untuk memperkuat penelitian ini, didukung oleh penelitian yang sejenis juga relevan dengan penelitian ini. Penelitian terdahulu yang sejenis pertama oleh Haezer pernah menegaskan bahwa internet mempunyai daya untuk dapat menjadi ruang publik yang sempurna jika didorong oleh kondisi tertentu yaitu kemauan dari para pengguna internet untuk menciptakan ruang publik virtual sendiri. (Haezer, 2018). Penelitian ini dilakukan oleh Haezer pada tahun 2018. Penelitian lain pernah dilakukan oleh Salman dengan tujuan guna mengetahui pola komunikasi ruang publik digital yang terjadi dan dijalankan di kalangan masyarakat. Penelitian oleh Salman ini memanfaatkan pendekatan kualitatif dengan metode deskriptif. Hasil yang didapatkan oleh Salman ini menyatakan pemanfaatan media sosial sebagai ruang publik digital bukan sekadar didominasi oleh masyarakat biasa, tetapi dimanfaatkan juga oleh pejabat pemerintahan untuk menjalin komunikasi dengan masyarakat. (Salman, 2017).

$$
\text { Selain itu, Nasrullah }
$$
mengungkapkan bahwa setiap anggota yang ada di dalam virtual room sadar bahwa mereka bertingkah sebagai anggota dari virtual room itu. (Nasrullah, 2012). Tujuan dari penelitin ini adalah untuk "memperjelas 
secara teori bagaimana internet akan menjadi panggung untuk diskusi kritis". Penelitian ini ditulis dengan menggunakan pendekatan teoritis. Penelitian lain oleh Istiarani dan Kurniasari menemukan hasil mengenai ruang public pada masyarkat merupakan tempat terjadinya interaksi tanpa batas (Istiarni \& Kurniasari, 2020). Supriadi dalam penelitiannya yang bertujuan untuk menggali asal usul jurnalisme publik dengan pandangan Habermas menemukan bahwa dalam pandangan Habermas, ruang publik mempunyai dua jenis yaitu ruang publik politik dan ruang publik sastra. (Supriadi, 2017).

Wasisto Raharjo Jati dalam penelitiannya menemukan kesimpulan bahwa kemunculan media sosial telah membawa tempat-tempat ruang publik baru ke kelas menengah di Indonesia.(Jati, 2016). Penelitian ini memilki tujuan untuk menganalisis cyberspace sebagai ruang publik baru untuk masyarakat menengah di Indonesia. Penelitian mengenai penggunaan twitter yang ditulis menemukan hasil bahwa media sosial twitter bisa digunakan sebagai salah satu wadah untuk berkomunikasi secara dua arah. (Fahmi \& Wibowo, 2017). Menurut penelitian lain, facebook, twitter, serta yahoo messenger merupakan sosial media yang paling banyak diminati saat ini. (Atmojo, 2015).

Sementara itu, (Simamarta, 2014) menegaskan bahwa media baru dapat berkontribusi pada pembentukan ruang publik yang universal serta dapat digunakan oleh semua orang. Sehingga masyarakat tidak mengalami kesulitan dalam mengekspresikan pendapatnya.

Perbedaan penelitian ini dengan penelitian di masa lalu ada pada media yang digunakan untuk berkomunikasinya. Pada penelitian sebelumnya, konteks media komunikasi yang dibahas lebih luas yaitu sosial media secara umum. Sedangkan penelitian ini hanya membahas instagram sebagai ruang publik yang digunakan oleh
BEMP Ilmu Komunikasi Universitas Negeri Jakarta sebagai transformasi informasi.

Teori ruang publik oleh Habermas digunakan dalam penelitian ini. Menurut Habermas, ruang publik adalah tempat orang dapat mengekspresikan sikap dan argumennya mengenai negara maupun pemerintahan. Habermas juga mengkategorikan ruang publik menjadi beberapa kategori : pluralitas, publisitas, keprivatan, dan legalitas. Ruang publik yang digunakan dalam penelitian ini adalah jenis publisitas sebab dalam publisitas itu mencakup media massa. Hal ini sesuai dengan penelitian ini sebab dalam penelitian ini menggunakan media massa sebagai tempat publisitas. Media sosial yang digunakan pada penelitian ini adalah Instagram.

Berdasarkan teori Habermas yang digunakan, penggunaan instagram oleh BEMP Ilmu Komunikasi UNJ dapat dikategorikan sebagai ruang publik sebab di dalamnya terjadi pertukaran informasi dan argumen antara para pengikutnya. Terjadinya transformasi informasi ini dimulai ketika BEMP Ilmu Komunikasi UNJ menyampaikan sebuah informasi melalui akun instagramnya dan kemudian para pengikut dari akun tersebut memberikan tanggapan atau komentar mengenai informasi yang disampaikan. Pernyataan ini sama dengan pernyataan Habermas yaitu ruang publik merupakan tempat dimana terjadinya penyampaian argumen oleh masyarakat. Dengan demikian, maka dapat dikatakan bahwa rauang Instagram merupakan ruang publik yang digunaka oleh BEMP Imu Komunikasi UNJ.

Selain menggunakan teori Habermas, penelitian ini juga menggunakan teori media richness theory. Teori ini kali pertama disampaikan oleh Daft dan Lengel yang mengatakan "kekayaan" suatu media merupakan faktor yang menentukan kegunaan suatu media. Media richness theory ini terkait dengan penentuan 
penggunaan media komunikasi yang ideal untuk menyelesaikan informasi yang tidak jelas dan tidak pasti. "Media yang kaya" dianggap lebih tepat untuk digunakan dibandingkan "media yang miskin", sebab "media kaya" tidak memerlukan waktu lama dalam menginformasikan pesan.

Daft dan Lengel mengungkapkan empat kriteria, yaitu : (1) Kesegaran, yaitu kemampuan media untuk menyampaikan informasi secara langsung dan tepat waktu sehingga bisa mendapat umpan balik secepat mungkin. (2) Keragaman isyarat, yaitu penggunaan pendekatan verbal serta nonverbal dalam menyampaikan informasi. (3) Bahasa yang beragam, untuk meningkatkan pemahaman terhadap informasi yang diberikan melalui simbol bahasa. (4) Sumber personal, yaitu kemampuan media untuk menyampaikan emosi dan perasaan yang terkandung dalam informasi yang disampaikan oleh pihak-pihak yang sedang berkomunikasi.

Media Richness Theory diciptakan dengan pandangan bahwa keberadaan sosial dan fisik bisa meningkatkan "kekayaan" dari suatu media. MRT telah dikembangkan kriterianya oleh Sproul dan Valacich, yaitu : (1) Keragaman penerima, yaitu media memiliki keahlian untuk menyampaikan informasi kepada banyak penerima di saat yang bersamaan. (2) Perekaman eksternal, yaitu kemampuan media untuk mendokumntasikan serta memodifikasi proses komunikasi. (3) Memori yang dapat diproses oleh komputer, maksudnya adalah kemampuan untuk mengelola informasi secara elektronik, misalnya dapat diperoleh melalui proses pencarian. (4) Konkurensi, yaitu berkaitan dengan kemampuan suatu media untuk memberikan fasilitas interaksi dengan banyak pengguna di waktu yang bersamaan.

Media Richness Theory digunakan dalam penelitian ini karena dianggap sesuai untuk dipergunakan sebagai kerangka sebab teori ini menjelaskan tentang kemampuan media sebagai sarana untuk transformasi informasi dan berkomunikasi. Hal ini sesuai untuk melihat apakah pengaruh yang terjadi dengan penggunaan media Instagram sebagai sarana transformasi informasi oleh BEMP Ilmu Komunikasi Universitas Negeri Jakarta.

Berdasarkan latar belakang yang sudah dipaparkan di atas maka dapat disimpulkan bahwa penelitian ini dilakukan berdasarkan ketertarikan penulis untuk mengetahui transformasi informasi yang terjadi pada ruang publik instagram. Dengan memiliki tujuan yaitu untuk mengetahui proses transformasi informasi yang terjadi di akun instagram BEMP Ilmu Komunikasi Universitas Negeri Jakarta

\section{METODOLOGI}

Pendekatan kualitatif digunakan dalam penelitian ini. Menurut Denzin \& Lincoln metode penelitian kualitatif didefinisikan sebagai penelitian dengan tujuan untuk menjelaskan suatu fenomena yang terjadi serta sekaligus mengikutsertakan bermacammacam metode untuk melakukannya. Sifat metode kualitatif ini sangat beragam, kompleks, dan dinamis, sedangkan realitas kebenaran bersifat dinamis. (Mulyana, 2013 :147). Selain itu, pemahaman sekaligus proses dalam penelitiannya sesuai dengan metode masalah manusia sekaligus fenomena sosial. Oleh karena itu dalam penelitian ini peneliti ingin memahami ruang publik Instagram BEMP Ilmu Komunikasi Universitas Negeri Jakarta sebagai transformasi informasi. Publik yang dimaksud pada penelitian ini adalah masyarakat. Masyarakat sebagai publik dari penelitian ini membutuhkan informasi terkait dengan akun BEMP Ilmu Komunikasi Universitas Negeri Jakarta yaitu ketika akun instagram BEMP Ilmu Komunikasi Universitas Negeri Jakarta memberikan informasi misalnya terkait adanya seminar atau pun acara lain yang dapat melibatkan masyarakat umum. Dalam penelitian kulitatif menggunakan dasar post-positivisme karena meneliti objek alam. Menurut Bogdan dan 
Biklen, penelitian kualitatif memiliki ciri-ciri (1) Dilakukan dalam keadaan yang bukan percobaan. Untuk akses langsung ke sumber data, peneliti adalah alat kunci, (2) Bersifat deskriptif. Informasi dikumpulkan berupa bacaan atau foto. Sehingga tidak focus terhadap angka (3) penelitian kualitatif lebih menitikberatkan pada proses daripada produk atau hasil, (4) penelitian kualitatif melakukan analisis informasi secara induktif, dan (5) penelitian kualitatif lebih menekankan pada makna. Penelitian kualitatif pada dasarnya memiliki dua tujuan khusus, yaitu deskripsi dan ekspresi, kemudian lukisan dan interpretasi.Riset kualitatif melaksanakan analisis informasi secara induktif, serta (5) Penelitian kualitatif menekankan pada arti (mengamati informasi terbalik). Pada dasarnya penelitian kualitatif mempunyai dua maksud tertentu yaitu menggambarkan dan mengungkapkan, lalu menggambar.

Dalam memahami yang akan diteliti, peserta penelitian mewawancarai partisipan dengan memberikan beberapa pertanyaan yang standar serta agak luas. Lalu informasi tersebut dikumpulkan yang pada umumnya berupa teks ataupun kata-kata. Dari data-data tersebutlah peneliti menginterpretasi untuk mengungkap arti terdalam secara naratif. Pada penelitian ini, peneliti menggunakan variabel ruang publik dan transformasi informasi. Objek dalam penelitian ini meliputi tempat penelitian, teknik penelitian dan sasaran penelitian. Tempat penelitian yang dilakukan di lingkungan kampus Universitas Negeri Jakarta. Pengambilan data dengan teknik kualitatif untuk penelitian ini dengan cara wawancara dan observasi. Tujuan wawancara untuk mengetahui bagaimana ruang publik Instagram BEMP Ilmu Komunikasi sebagai transformasi informasi. Subjek dalam penelitian ini adalah followers akun Instagram BEMP Ilmu Komunikasi Universitas Negeri Jakarta, peneliti mewawancarai informan sebanyak 4 orang dengan kriteria yaitu informan pertama (HN) merupakan salah satu followers akun Instagram BEMP Ilmu Komunikasi
Universitas Negeri Jakarta yang sangat aktif, informan kedua (YP) merupakan salah satu followers akun Instagram BEMP Ilmu Komunikasi Universitas Negeri Jakarta yang aktif, informan ketiga (KA) merupakan salah satu followers akun Instagram BEMP Ilmu Komunikasi Universitas Negeri Jakarta yang cukup aktif, serta informan keempat (FM) merupakan salah satu followers akun Instagram BEMP Ilmu Komunikasi Universitas Negeri Jakarta yang kurang aktif.

\section{HASIL DAN PEMBAHASAN}

Penelitian ini memiliki jumlah informan sebanyak empat orang. Peneliti sudah mendapatkan banyak informasi dari jumlah informan tersebut.Informan dalam penelitian ini bernama HN\#1, YA\#2, KA\#3, dan LF\#4. Berikut ini profil dari 4 orang yang menjadi informan:

HN\#1, merupakan seorang informan dengan jenis kelamin perempuan yang saat ini berusia 19 tahun dan sedang menyelesaikan S1 nya di Program Studi Ilmu Komunikasi Universitas Negeri Jakarta. Bertempat tinggal di Jl. Kelapa Nias III Blok PA 9/1, Kelapa Gading, Jakarta Utara, 14250. Bergaman Islam dan merupakan anak tunggal. Informan menyadari bahwa dirinya berpartisipasi aktif dalam mengikuti setiap kegiatan yang dilaksanakan oleh BEMP Ilmu Komunikasi Universitas Negeri Jakarta, ia senantiasa mengikuti Instagram BEMP Ilmu Komunikasi Universitas Negeri Jakarta sebagai ruang publik.

YA\#2, merupakan seorang informan dengan jenis kelamin perempuan yang saat ini berusia 19 tahun dan sedang menyelesaikan S1 nya di Program Studi Ilmu Komunikasi Universitas Negeri Jakarta, beragama Islam, ia memiliki empat saudara dan merupakan anak kedua. Informan bertempat tinggal di Bertempat tinggal di jalan Damai RT. 001/04 No. 91, Ketapang Dongkal, Poris Indah, Cipondoh, Kota Tangerang, 15148. Informan menyadari bahwa ia memiliki partisipasi aktif dan memiliki intensitas dalam melihat Instagram 
BEMPL Ilmu Komunikasi Universitas Negeri Jakarta sebagai ruang publik.

KA\#3, merupakan seorang informan dengan jenis kelamin perempuan yang saat ini berusia 19 tahun dan sedang menyelesaikan S1 nya di Program Studi Ilmu Komunikasi Universitas Negeri Jakarta, beragama Islam, memiliki tiga saudara, dan merupakan anak kedua. Informan bertempat tinggal di Jl.nusa indah 6 gg.11 no.230 rt.08 rw.03 Kelurahan Malaka Jaya Kecamatan Duren Sawit, Jakarta Timur. Informan menyadari bahwa ia memiliki partisipasi lumayan aktif dalam melihat Instagram BEMP Ilmu Komunikasi Universitas Negeri Jakarta sebagai ruang publik.

LF\#4, merupakan seorang informan dengan jenis kelamin perempuan yang saat ini berusia 19 tahun dan sedang menyelesaikan S1 nya di Program Studi Ilmu Komunikasi Universitas Negeri Jakarta, beragama Islam, anak ke satu dari dua bersaudara. Informan bertempat tinggal di Tambun Selatan, Bekasi Timur. Informan menyadari bahwa ia memiliki partisipasi dan intensitas kurang aktif dalam melihat Instagram BEMP Ilmu Komunikasi Universitas Negeri Jakarta sebagai ruang publik.

Konten yang diposting dalam Instagram BEMP Ilmu Komunikasi Universitas Negeri Jakarta yaitu feed dan instagram story yang nantinya dijadikan sebagai highlight. Konten feed yang diposting dalam Instagram BEMP Ilmu Komunikasi Universitas Negeri Jakarta meliputi konten informasi mengenai informasi program kerja yang sedang dijalankan seperti diskusi komunikatif, seniorun, eksploraself, dan kompedia. Sedangkan highlight yang terdapat dalam Instagram BEMP Ilmu Komunikasi seperti filosofi logo, PKKMB, PKMP, fun fact, dan kegiatan yang dilaksanakan oleh setiap departemen yang terdapat dalam BEMP Ilmu Komunikasi Universitas Negeri Jakarta.

Dalam Instagram BEMP Ilmu Komunikasi Universitas Negeri Jakarta yang dapat mempengaruhi pengetahuan informasi audiensnya seperti konten kompedia dan perayaan hari-hari besar.

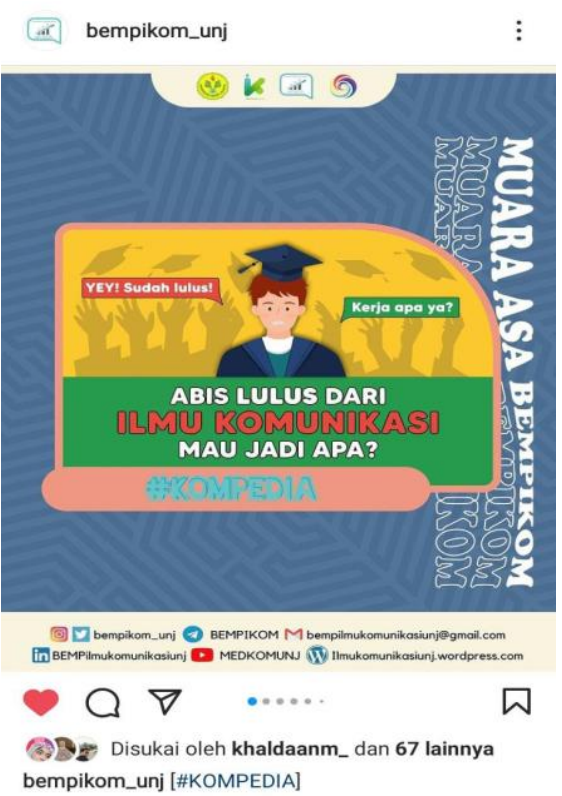

Gambar 1. Konten Instagram

(Sumber : Instagram BEMP Ilmu Komunikasi Universitas Negeri Jakarta)

Salah satu konten instagram BEMP Ilmu Komunikasi Universitas Negeri Jakarta yang dapat mempengaruhi pengetahuan audiens yaitu konten kompedia. Dalam konten kompedia berisi informasi mengenai informasi yang berkaitan dengan komunikasi, salah satunya mengenai prospek kerja jurusan ilmu komunikasi. Dalam konten kompedia yang dipublikasikan memberikan informasi seputar prospek kerja jurusan ilmu komunikasi seperti presenter, jurnalis, public relations, periklanan, penyiar radio, dan dosen.

Dalam Instagram BEMP Ilmu Komunikasi Universitas Negeri Jakarta terdapat konten-konten yang bersifat umum seperti konten perayaan hari-hari besar yaitu hari buku nasional, hari kenaikan Isa Almasih, hari Raya Idul Fitri, dan perayaan hari besar lainnya. Tidak hanya itu saja, kontenkonten yang bersifat umum seperti informasi penyelenggaraan diskusi atau seminar seperti diskusi komunikatif dan seminar we heal. Dalam Instagram BEMP Ilmu Komunikasi Universitas Negeri Jakarta juga terdapat konten hiburan seperti komfide yang 
menyajikan konten-konten seperti informasi mengenai ilmu komunikasi dan cerita pengalaman mahasiswa ilmu komunikasi.

Ruang publik media sosial Instagram digunakan oleh BEMP Ilmu Komunikasi Universitas Negeri Jakarta sebagai wadah yang menampung transformasi informasi kepada publik. Ruang publik media sosial Instagram BEMP Ilmu Komunikasi Universitas Negeri Jakarta merupakan tempat dalam membagikan setiap postingan kegiatan yang dilaksanakan oleh BEMP Ilmu Komunikasi dalam menyampaikan informasi kepada publik.

Menurut teori ruang publik, media sosial merupakan tempat untuk mengkespresikan diri dan memberikan argumen secara bebas. Instagram BEMP Ilmu Komunikasi Universitas Negeri Jakarta sudah mampu menjadi wadah yang bebas menyatakan sikap dan argumen karena dapat menjadi wadah yang bebas dalam artian sebagai pengikut Instagram BEMP Ilmu Komunikasi bebas untuk berkomentar mengenai sikap atau argumen audiensi atau followers pada setiap postingan atau story Instagram BEMP Ilmu Komunikasi Universitas Negeri Jakarata, tidak hanya itu saja Instagram BEMP ilmu komunikasi Universitas Negeri Jakarta sering membuka question box di story, sehingga followers dapat menyampaikan pendapat dan Instagram terdapat fitur direct message yang terbuka untuk followers untuk menyampaikan pesan, sedangkan menurut salah satu informan dalam menyampaikan argumen dapat dilakukan secara lebih profesi melalui direct message atau komen Instagram seperti yang terlihat pada gambar 2. Apabila dikaitkan dengan penelitian sebelumnya oleh wasisto Raharjo jati dengan judul penelitian media and political representation the role of media in Indonesia presidential campaign 2001-2009 yang menemukan bahwa kemunculan media sosial membawa tempat-tempat ruang publik baru ke kelas menengah di Indonesia. Dalam penelitian ini menggunakan media sosial
Twitter yang menyatakan bahwa media sosial dapat dijadikan sebagai salah satu wadah untuk berkomunikasi secara dua arah. Penemuan sebelumnya memperkuat penemuan dalam penelitian ini, yang menyatakan bahwa media sosial Instagram juga dapat menjadi wadah yang bebas menyatakan sikap dan argumen melalui berbagai fitur yang disediakan oleh Instagram, sehingga dapat menjadi ruang publik yang mampu atau dapat dijadikan sebagai wadah komunikasi dua arah.

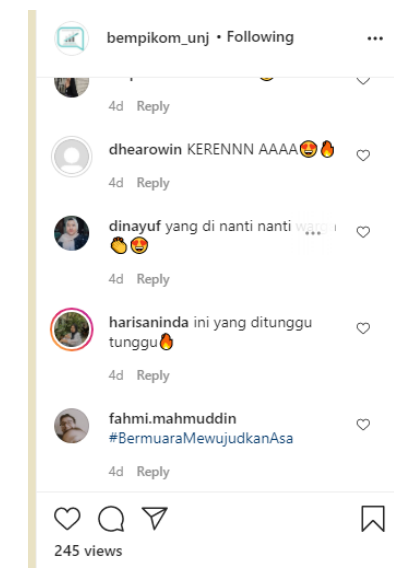

Gambar 2. Sikap dan Argumen

(Sumber : Instagram BEMP Ilmu Komunikasi Universitas Negeri Jakarta)

Ketika menyampaikan informasi kepada publik melalui media sosial Instagram BEMP ilmu komunikasi Universitas Negeri Jakarta, tentunya intensitas dalam memposting setiap konten merupakan salah satu indikator penting. Dengan adanya intensitas dari postingan akun Instagram BEMP Ilmu Komunikasi Universitas Negeri Jakarta dapat mempengaruhi pengetahuan informasi followersnya. Menurut hasil wawancara dari empat informan, keempatnya menyatakan bahwa setiap postingan yang dibagikan akan melewati beranda instagramnya, bahkan terkadang mereka mengunjungi akun Instagram BEMP Ilmu Komunikasi Universitas Negeri Jakarta. Akun Instagram BEMP Ilmu Komunikasi Universitas Negeri Jakarta intens dalam memposting setiap 
postingan atau snapgram mengenai setiap kegiatan baik proker maupun non proker dari BEMP Ilmu Komunikasi Universitas Negeri Jakarta, perayaan hari-hari besar, dan kontenkonten hiburan. Ssetiap postingan yang diupload cukup intens mulai dari awal periode hingga akhir periode.

Penyampaian Informasi yang disampaikan oleh akun Instagram BEMP Ilmu Komunikasi Universitas Negeri Jakarta juga mempengaruhi intensitas dalam melihat setiap postingan yang dibagikan oleh akun Instagram BEMP ilmu komunikasi Universitas Negeri Jakarta. Menurut hasil wawancara yang disampaikan oleh informan, mereka menyatakan bahwa setiap postingan yang dibagikan oleh akun Instagram BEMP Ilmu Komunikasi Universitas Negeri Jakarta cukup informatif, menarik, eye catching dan postingan yang dibagikan tidak monoton, selain itu setiap postingan yang dibagikan memiliki cara penyampaian yang kreatif dan mudah dimengerti oleh followers akun Instagram BEMP Ilmu Komunikasi Universitas Negeri Jakarta. Informasi yang bergulir sudah mewakili sebagai ruang publik karena dari sifat publikasi dan kontenkontennya pun bersifat umum tidak hanya untuk konsumsi oleh BEMP Ilmu Komunikasi Universitas Negeri Jakarta sendiri maupun prodi Ilmu Komunikasi Universitas Negeri Jakarta sendiri dan juga dari sosial media itu dan bersifat publik tidak di private sehingga siapapun dapat mengunjungi akun Instagram BEMP Ilmu Komunikasi Universitas Negeri Jakarta. Informasi yang bergulir juga terkait mengenai akademik, acara BEMP, perayaan hari besar, dan konten hiburan. Salah satu narasumber juga menyampaikan bahwa informasi yang disampaikan dapat membantunya untuk mengetahui informasi seperti peringatan hari-hari besar melalui akun Instagram BEMP Ilmu Komunikasi Universitas Negeri Jakarta.

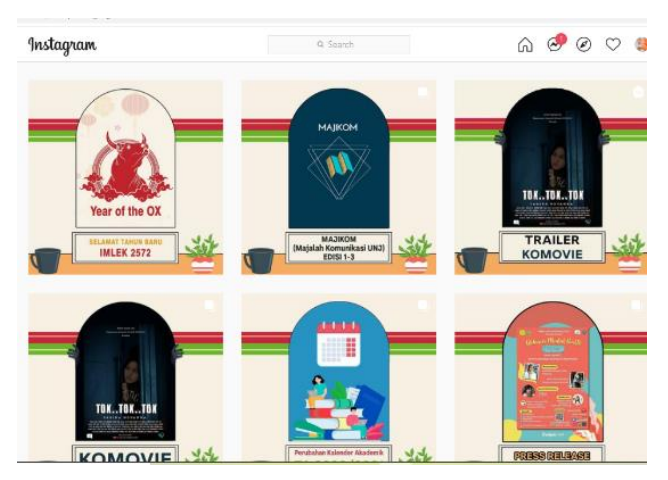

Gambar 3. Postingan Instagram BEMP Ilmu

Komunikasi Universitas Negeri Jakarta (Sumber : Instagram BEMP Ilmu

Komunikasi Universitas Negeri Jakarta)

Pluralisme terlihat dari setiap postingan atau story dari Instagram BEMP Ilmu komunikasi Universitas Negeri Jakarta seperti pada gambar 2 di atas yang terdapat postingan dalam memperingati hari-hari besar dari setiap agama seperti postingan tentang peringatan Hari Natal, Hari Raya Idul Fitri, dan Hari Raya Nyepi. Menurut salah satu informan pluralisme yang terjadi dalam Instagram BEMP Ilmu Komunikasi Universitas Negeri Jakarta seperti yang sudah cukup baik seperti peringatan hari raya umat Imlek yang diperlihatkan pada gambar 3 dan setiap perayaan agama diumumkan serta hal tersebut menunjukkan adanya toleransi keberagaman dalam Instagram BEMP Ilmu Komunikasi yang tentunya menghargai setiap perbedaan yang ada karena anggota BEMP ilmu komunikasi Universitas Negeri Jakarta pun beragam. Pluralisme sudah memposting sesuai dengan porsinya sebagai akun Instagram BEM ilmu komunikasi Universitas Negeri Jakarta. Selain itu postingan konten ilmu komunikasi Universitas Negeri Jakarta menurut narasumber sudah cukup adil dan merata mulai dari postingan keagamaan tidak dibeda-bedakan kemudian postingan harihari besar dan informasi mengenai setiap departemen dari BEMP Ilmu Komunikasi Universitas Negeri Jakarta 


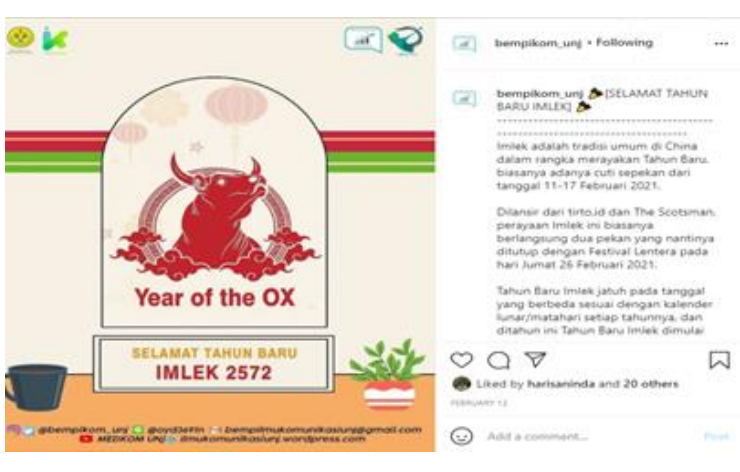

Gambar 4. Postingan Konten Pluralisme BEMP Ilmu Komunikasi Universitas Negeri Jakarta (Sumber: Instagram BEMP Ilmu Komunikasi Universitas Negeri Jakarta)

Terlihat juga pada gambar 4 bahwa pemilihan konten, waktu posting, dan caption dalam akun Instagram BEMP sudah tepat, informan dalam wawancara ini menyampaikan bahwa setiap postingan konten menyampaikan informasi mengenai setiap kegiatan yang dilaksanakan oleh BEMP Ilmu Komunikasi Universitas Negeri Jakarta, waktu memposting setiap konten disesuaikan dengan jam yang traffic sehingga mampu menjaring audiens atau publik lebih banyak, caption yang disampaikan sebagai keterangan dalam konten yang diposting juga sesuai atau memiliki kesinambungan dengan konten postingan.

Menurut para informan dalam wawancara ini, setiap pesan yang disampaikan melalui postingan akun Instagram BEMP Ilmu Komunikasi Universitas Negeri Jakarta mudah di mengerti dan diterima karena menggunakan pemilihan kata-kata yang sopan, tidak baku, dan tersusun dengan baik, sehingga publik merasa lebih mudah mengerti dan menerima pesan atau informasi yang disampaikan.

Pada teori ruang publik terdapat beberapa jenis salah satunya publisitas. Publisitas yang sering muncul dari Instagram BEMP Ilmu Komunikasi Universitas Negeri Jakarta mengenai konten-konten informasi mengenai kegiatan BEMP Ilmu Komunikasi Universitas Negeri Jakarta dan kontenkonten hiburan-hiburan. Pada dasarnya publisitas merupakan penyebaran sejumlah informasi mengenai sessuatu seperti sasaran, barang, atau organisasi tanpa dikenakan biaya sepeserpun. Publisitas juga menjadi alat pelengkap dalam promosi untuk menarik perhatian khalayak. (Liliweri, 2011)

Reaksi terhadap publisitas yang sering muncul dalam akun Instagram BEMP ilmu komunikasi Universitas Negeri Jakarta yaitu positif karena akun tersebut dapat menjadi galeri perjalanan setiap followers karena berisi kegiatan-kegiatan BEM pada umumnya. Selain itu reaksi yang muncul banyak followers yang merasa tertarik karena setiap konten yang menarik sehingga setiap followers mengikuti dan menyimak informasi-informasi yang ada bahkan terkadang merepost setiap postingan dari Instagram BEMP ilmu komunikasi Universitas Negeri Jakarta.

Melalui akun instagram BEMP Ilmu Komunikasi Universitas Negeri Jakarta tentunya membuat publik yang memiliki atau menambah informasi mengenai berbagai kegiatan yang dilaksanakan oleh BEMP Ilmu Komunikasi Universitas Negeri Jakarta seperti yang sudah dijelaskan dalam Media Richness Theory terdapat transofrmasi informasi kepada followers. Selain itu akun Instagram BEMP Ilmu Komunikasi Universitas Negeri Jakarta tidak hanya menyampaikan berbagai macam kegiatan yang dilaksanakan, akan tetapi juga memiliki konten hiburan seperti comfide dan stokom yang membuat akun Instagram BEMP Ilmu Komunikasi Universitas Negeri Jakarta memiliki daya tarik sehingga publik dapat berpartisipasi atau berinteraksi dengan setiap konten yang dibagikan secara aktif.

Media Richness Theory juga menjelaskan adanya komunikasi yang terjadi, dengan akun Instagram BEMP ilmu komunikasi Universitas Negeri Jakarta para followers atau publik dapat memberikan saran dan kritik melalui direct message atau kolom komentar yang sudah disediakan dalam fitur Instagram terkadang juga 
menyampaikannya melalui question box

yang disebar lewat story Instagram.

Tabel 1. Ruang Publik Instagram Sebagai Transformasi Informasi

\begin{tabular}{|c|c|c|c|c|c|}
\hline No & Aspek-Aspek & \multicolumn{4}{|c|}{ Inisial Narasumber Penelitian } \\
\hline 1. & $\begin{array}{l}\text { Sikap dan } \\
\text { argument }\end{array}$ & $\begin{array}{l}\quad \text { HN } \\
\text { Berkomentar } \\
\text { mengenai konten } \\
\text { yang dipost pada } \\
\text { feeds ataupun } \\
\text { story instagram }\end{array}$ & \begin{tabular}{l}
\multicolumn{1}{c}{ YP } \\
Instagram BEMP \\
Ilmu Komunikasi \\
UNJ seringkali \\
membuka \\
question box di \\
story, sehingga \\
audiens dapat \\
menyampaikan \\
pendapatnya
\end{tabular} & \begin{tabular}{l}
\multicolumn{1}{c}{ KA } \\
Bebas untuk \\
berkomentar \\
mengenai sikap \\
atau argumen di \\
postingan atau \\
story dari \\
instagram BEMP \\
ilmu komunikasi \\
UNJ
\end{tabular} & \begin{tabular}{l}
\multicolumn{1}{c}{ FM } \\
Menyampaikan \\
argumen \\
dilakukan secara \\
lebih privasi \\
melalui direct \\
message
\end{tabular} \\
\hline 1. & Intensitas & $\begin{array}{l}\text { Sering } \\
\text { memposting } \\
\text { setiap kegiatan } \\
\text { yang berkaitan } \\
\text { dengan BEMP } \\
\text { Ilmu Komunikasi } \\
\text { Negeri Jakarta }\end{array}$ & $\begin{array}{l}\text { Intens dalam } \\
\text { memposting }\end{array}$ & $\begin{array}{l}\text { Cukup intens dan } \\
\text { konsisten dalam } \\
\text { mengupload } \\
\text { postingan }\end{array}$ & $\begin{array}{l}\text { BEMP Ilmu } \\
\text { Komunikasi } \\
\text { Universitas Negeri } \\
\text { Jakarta intens } \\
\text { dalam } \\
\text { mengupload } \\
\text { postingan, } \\
\text { misalkan ada } \\
\text { acara BEMP Ilmu } \\
\text { Komunikasi } \\
\text { Universitas Negeri } \\
\text { Jakarta atau hari- } \\
\text { hari besar lainnya. }\end{array}$ \\
\hline 2. & $\begin{array}{l}\text { Penyampaian } \\
\text { Informasi }\end{array}$ & $\begin{array}{l}\text { Cara } \\
\text { penyampaian } \\
\text { informasi yang } \\
\text { mudah } \\
\text { dimengerti dan } \\
\text { konten-konten } \\
\text { yang diposting } \\
\text { berkaitan dengan } \\
\text { kegiatan BEMP } \\
\text { Ilmu Komunikasi } \\
\text { Universitas } \\
\text { Negeri Jakarta }\end{array}$ & $\begin{array}{l}\text { Informasi yang } \\
\text { bergulir sudah } \\
\text { mewakili dari } \\
\text { ruang publik, } \\
\text { karena kontennya } \\
\text { bersifat umum }\end{array}$ & $\begin{array}{l}\text { Informasi yang } \\
\text { disampaikan sangat } \\
\text { informatif sehingga } \\
\text { menambah } \\
\text { pengetahuan } \\
\text { followers }\end{array}$ & $\begin{array}{l}\text { Informasi yang } \\
\text { bergulir di } \\
\text { Instagram BEMP } \\
\text { Ilmu Komunikasi } \\
\text { hanya terkait } \\
\text { akademik, acara } \\
\text { BEMP Ilmu } \\
\text { Komunikasi atau } \\
\text { perayaan hari } \\
\text { besar. meskipun } \\
\text { termasuk ruang } \\
\text { public, akan tetapi } \\
\text { akun tersebut } \\
\text { memang untuk } \\
\text { BEMP Ilmu } \\
\text { Komunikasi jadi } \\
\text { informasi yang } \\
\text { disampaikan } \\
\text { sudah sesuai }\end{array}$ \\
\hline 3. & Pluralisme & $\begin{array}{l}\text { Sudah cukup } \\
\text { baik, seperti } \\
\text { peringatan hari } \\
\text { raya umat }\end{array}$ & $\begin{array}{l}\text { Memperingati } \\
\text { hari-hari besar } \\
\text { dari setiap agama } \\
\text { seperti postingan }\end{array}$ & $\begin{array}{l}\text { Informasi yang } \\
\text { disampaikan cukup } \\
\text { beragam, jadi } \\
\text { bukan hanya }\end{array}$ & $\begin{array}{l}\text { Dalam instgaram } \\
\text { tersebut tentunya } \\
\text { menghargai } \\
\text { perbedaan yang }\end{array}$ \\
\hline
\end{tabular}


beragama, setiap perayaan agama diumumkan dan hal tersebut menunjukan adanya toleransi keberagamaan dalam instagram BEMP ilmu komunikasi UNJ

4. Kesesuaian Sudah tepat

5. Penerimaan Pesan

6. Publisitas

7. Reaksi Publisitas 8. Pemanfaatan
Instagram

Dapat diterima dan dimengerti sering muncul adalah informasi terkait prodi ilmu komunikasi, seperti pengumuman SBMPTN, SNMPTN, dan peringatan harihari besar.

Reaksinya sangat baik, informasi yang sangat menjawab pertanyaan mahasiswa mengenai suatu acara atau informasi terkait prodi ilmu komunikasi.

Untuk menyatakan mengenai peringatan Hari Natal, hari raya Idul Fitri, Hari Raya Nyepi.

Sudah tepat

Publisitas yang disampaikan juga kritik dan saran bisa melalui komentar di postingan atau melalui direct message kata-katanya baik Komunikasi release, dll pengikut pengikutnya, umumnya direct message menyebar

informasi seputar

BEMP Ilmu

Komunikasi UNJ, namun juga terkait eksternal seperti isu kampus dan hal yang lebih umum, misalnya peringatan Hari Raya

Pemilihan konten, Sudah tepat waktu posting dan caption instagram sudah tepat

Dapat dipahami karena pemilihan sopan dan tersusun

Publisitas yang sering muncul dari Instagram BEMP Ilmu mengenai konten hiburan, hari hari besar, press

Reaksi yang Karena menarik, muncul dari jadi saya pribadi Instagram BEMP Ilmu Komunikasi pun positif, karena bisa menjadi galeri perjalanan bagi informasiinformasi yang ada, bahkan kadang karena berisi kegiatan-kegiatan bem pada

Lewat question box yang disebar lewat story, atau bisa juga lewat selalu mengikuti dan menyimak

Karena postingan yang disampaikan dapat diterima dan mengandung $5 \mathrm{w}+1$ h serta bahasanya mudah dimengerti

Informatif
menarik sekali

dan Saya kurang sering melihat konten di Instagram BEMP Ilmu Komunikasi, hanya sesekali dan publisitas nya sudah sesuai dgn waktu, sikon untuk mengupload konten tersebut

Kurang sering melihat konten di Instagram BEMP Ilmu Komunikasi
Menyampaikannya Melalui direct melalui direct message message 


\begin{tabular}{|c|c|c|c|c|c|}
\hline 9. & Pengetahuan & $\begin{array}{l}\text { Iya, karena } \\
\text { menyediakan } \\
\text { konten } \\
\text { bermanfaat }\end{array}$ & $\begin{array}{l}\text { Menambah } \\
\text { pengetahuan dan } \\
\text { informasi }\end{array}$ & $\begin{array}{l}\text { Menyediakan } \\
\text { konten bermanfaat, } \\
\text { selain berbentuk } \\
\text { hiburan juga } \\
\text { terdapat informasi }\end{array}$ & $\begin{array}{l}\text { Menambah } \\
\text { pengetahuan }\end{array}$ \\
\hline 10 & $\begin{array}{l}\text { Penyampaian } \\
\text { saran dan } \\
\text { kritik }\end{array}$ & Tidak selalu & $\begin{array}{l}\text { Instagram } \\
\text { memiliki fitur } \\
\text { direct message dan } \\
\text { komen, jadi dapat } \\
\text { dengan mudah } \\
\text { menyampaikan } \\
\text { ide, kritik, maupun } \\
\text { saran }\end{array}$ & $\begin{array}{l}\text { Karena Instagram } \\
\text { BEMP Ilmu } \\
\text { Komunikasi kolom } \\
\text { komentarnya } \\
\text { dinyalakan dan } \\
\text { setiap direct } \\
\text { message selalu } \\
\text { ditanggapi dengan } \\
\text { cepat untuk } \\
\text { menyampaikan } \\
\text { saran dan ide } \\
\text { kepada BEMP Ilmu } \\
\text { Komunikasi UNJ }\end{array}$ & $\begin{array}{l}\text { Dapat } \\
\text { menyampaikan } \\
\text { kritik dan saran }\end{array}$ \\
\hline
\end{tabular}

Berdasarkan tabel 1. ruang publik Instagram sebagai transformasi informasi dapat diketahui bahwa sebagian besar narasumber menyatakan sikap dan argumennya melalui komentar setiap postingan, story, dan direct message. Setiap followers memiliki intensitas yang berbeda dalam melihat Instagram BEMP Ilmu Komunikasi Universitas Negeri Jakarta. Sebagian narasumber juga berpendapat bahwa penyampaian informasi mudah dimengerti, terdapat konten-konten mengenai keberagaman umat agama sehingga dapat menunjukkan pluralisme, setiap pesan yang disampaikan oleh akun Instagram BEMP Ilmu Komunikasi Universitas Negeri Jakarta dapat dimengerti dan diterima dengan baik oleh setiap followersnya. Publisitas yang sering muncul adalah konten-konten yang berkaitan dengan kegiatan yang dilaksanakan oleh akun Instagram BEMP Ilmu Komunikasi Universitas Negeri Jakarta. Sebagian besar narasumber juga memiliki reaksi yang positif terhadap setiap postingan, setiap postingan juga dapat memberikan pengetahuan dan informasi tambahan terhadap followers Instagram BEMP Ilmu komunikasi Universitas Negeri Jakarta, dan followers dapat menyampaikan saran dan kritiknya melalui fitur komentar dari setiap postingan, story Instagram, dan direct message pada akun Instagram BEMP Ilmu Komunikasi Universitas Negeri Jakarta. Hasil penelitian ini memperkuat hasil penemuan penelitian terdahulu bahwasanya media baru memiliki peran dan juga kontribusi terhadap pembentukan ruang publik yang universal serta dapat digunakan oleh semua orang, sehingga masyarakat tidak mengalami kesulitan dalam menyampaikan pendapatnya.

\section{SIMPULAN}

Kebutuhan terhadap ruang publik sebagai transformasi informasi berjalan beriringan dengan kebutuhan manusia. terhadap ruang agar dapat bersosialisasi dengan sesama untuk mendapatkan informasi. Hasil penelitian ini menunjukan bahwa transformasi informasi ruang publik Instagram BEMP Ilmu Komunikasi Universitas Negeri Jakarta sudah berjalan dengan baik, tentunya karena Instagram BEMP Ilmu Komunikasi mampu menjadi wadah yang bebas menyatakan sikap dan argumen followersnya. Pluralisme juga terlihat dari setiap postingan atau story Instagram BEMP Ilmu Komunikasi Universitas Negeri Jakarta yang berisi konten keagamaan, publisitas yang sering muncul yaitu mengenai konten-konten 
kegiatan BEMP Ilmu Komunikasi Universitas Negeri Jakarta sehingga mampu memberikan dan menambah informasi mengenai berbagai kegiatan yang dilaksanakan oleh BEMP Ilmu Komunikasi Universitas Negeri Jakarta. Reaksi terhadap setiap publisitas yang terdapat dalam akun Instagram BEMP Imu Komunikasi Universitas Negeri Jakarta sebagai ruang

\section{DAFTAR PUSTAKA}

Andri, K., Nibrasatul, Y., \& Erna, T. (2020). Resistensi Ruang Publikdi Tengah Covid-19 Perspektif Islam Dan Komunikasi Multikultural. Jurnal Komunike, 7, 24-40.

Anggito, A., \& Johan, S. (2018). Metodologi Penelitian Kualitatif (E. D. Lestari (ed.)). Sukabumi : CV Jejak.

Atmojo, J. T. (2015). Media Massa dan Ruang Publik. Jurnal Visi Komunikasi, 14(02), 223-238.

Dwihantoro, P., Rosyidi, M. I., \& Husna, A. N. (2020). Menakan New Media Sebagai Ruang Publik Dalam Konteks Kebhinekaan Di Magelang. Jurnal Komunikasi Dan Sosial Humaniora, 1, 1-10.

Fahmi, U., \& Wibowo, C. P. (2017). Ruang Publik Online: Sebuah Dimensi Baru Dalam Proses Pembuatan Kebijakan? (Studi Kasus Penggunaan Twitter Di Indonesia. International

Seminar:Reconstructing Public Administration Reform To Build World Class Government, 591-605.

Haezer, E. (2018). Menyoal Internet sebagai Ruang Publik Dalam Perspektif Habermas. Jurnal Dakwah Dan Komunikasi Islam, 4(2), 182-196.

Istiarni, A., \& Kurniasari, E. (2020). Peran Perpustakaan Digital Dalam Menciptakan Ruang Publik (Studi Kasus Perpustakaan Digital Universitas Lampung). Jurnal Ilmu publik yakni positif, dengan adanya akun Instagram BEMP Ilmu Komunikasi Universitas Negeri Jakarta membuat para followers atau publik dapat memberikan saran dan kritik melalui postingan, snapgram, dan direct message sehingga mampu menjadi ruang publik sebagai transformasi informasi.

Perpustakaan Dan Informasi, 15(1), 31-53.

Insani, C. N., Hidayat, D. R., \& Zulfan, I. (2019). Pemanfaatan Insta Story Dalam Aktivitas Jurnalistik Oleh Majalah Gadis. Jurnal Kajian Jurnalisme, $3(1), \quad 39$. https://doi.org/10.24198/jkj.v3i1.22 453

Jati, W. R. (2016). Cyberspace, Internet, Dan Ruang Publik Baru : Aktivisme Online Politik Kelas Menengah Indonesia. Jurnal Pemikiran Sosiologi, 3(1), 25-35.

Liliweri, A. (2011). Komunikasi Serba Ada Serba Makna. Kencana.

Nasrullah, R. (2012). Internet dan Ruang Publik Virtual, Sebuah Refleksi atas Teori Ruang Publik Habermas. Jurnal Komunikator, 4(1), 27-35.

Prihatiningsih, W. (2017). Motif Penggunaan Media Sosial Instagram Di Kalangan Remaja. Jurnal Communication VIII, 1, 5165.

Salman. (2017). Media Sosial Sebagai Ruang Publik. Jurnal Bisnis Dan Komunikasi, 4(2), 124-131.

Sari, D. N., \& Basit, A. (2020). Media Sosial Instagram Sebagai Media Informasi Edukasi Parenting. Persepsi: Communication Journal, 3(1), 23-36. https://doi.org/10.30596/persepsi.v $3 \mathrm{i} 1.4428$

Shaleh, A., \& Furrie, W. (2020). Peran Public Relations Dalam Pemanfaatan Instagram Sebagai Alat Publikasi Untuk Meningkatkan 
Layanan Masyarakat Di Puskesmas Kecamatan Cilincing (Studi Kasus Pada Akun Instagram @Puskesmascilincing) puskesmascilincing). LUGAS Jurnal Komunikasi, 4(1), 9-16. https://doi.org/10.31334/lugas.v4i1. 936

Simamarta, S. (2014). Media Baru, Ruang Publik Baru, Dan Transformasi Komunikasi Politik Di Indonesia. Interact, 3(2), 18-36.

Supriadi, Y. (2017). Relasi Ruang Publik Dan Pers Menurut Habermas. Kajian Jurnalisme, I(1), 1-20.

Tricana, D. W. (2013). Media Massa dan Ruang Publik (Public Sphere), sebuah Ruang yang hilang. Jurnal Aristo, 12(November), 8-13.

Wahyudin, D., \& Adiputra, C. P. (2019). Analisis Literasi Digital Pada Konten Instagram @Infinitigenre. Wacana: Jurnal Ilmiah Ilmu Komunikasi, 18(1), 25-34. https://doi.org/10.32509/wacana.v1 $8 \mathrm{i} 1.744$ 